\title{
Reflexões acerca da elaboração do Projeto PARTIDA: uma possibilidade de intervir artisticamente no cotidiano escolar
}

\section{Resumo}

Este trabalho faz reflexões sobre a elaboração do Projeto PARTIDA, uma ação de/sobre intervenção urbana pensada pedagogicamente para ser desenvolvida dentro do âmbito escolar. Como tentativa de diálogo entre a minha prática como artista-intervencionista e minha prática como docente, a pesquisa partiu de questionamentos sobre como aproximar práticas de intervenção urbana à escola. Como proposta de investigação, foi elaborado pedagogicamente um processo formativo que teve como foco a participação do educando intervindo artisticamente no cotidiano escolar. As principais referências teóricas que acompanharam a construção deste projeto foram Carminda Mendes André, que pesquisa e investiga ações interventivas e Jorge Larrosa Bondía, que conceitua a noção de experiência.

Palavras-chave: Intervenção Urbana. Projeto. Educação Básica. Experiência. Artista-docente.

\begin{abstract}
This work reflects about the elaboration of the Project PARTIDA, an action of/about urban intervention thought pedagogically to be developed within the school scope. As an attempt to dialogue between my practice as an interventionist artist and my practice as a teacher, the research started with questions about how to approach urban intervention practices to the school. As a research proposal, a formative process was elaborated that focused on the participation of the student artistically intervening in the daily school life. The main theoretical references that accompanied the construction of this project were Carminda Mendes André, who researches and investigates intervention actions and Jorge Larrosa Bondía, who conceptualizes the notion of experience.
\end{abstract}

Keywords: Urban Intervention. Project. Basic Education. Experience. Artist-teacher

O presente trabalho é um relato crítico sobre a elaboração do Projeto PARTIDA, uma ação de/sobre intervenção urbana pensada pedagogicamente para ser desenvolvida no âmbito escolar. Proposto e desenvolvido durante a realização da atividade de Estágio Supervisionado IV, do Curso de Teatro-Licenciatura da Universidade Federal do Ceará, o projeto desdobrou- 
se no trabalho de conclusão de curso, intitulado: Experiência e Intervenção Urbana: existir, resistir e ser mulher na escola, orientado pela professora Tharyn Stazak de Freitas.

Experiências como artista-intervencionista no PIBID-Teatro da UFC e no Coletivo Margens Urbanas foram essenciais na construção desse projeto, pois foi a partir desses lugares de atuação que surgiram os questionamentos iniciais. Como fazer com que uma ação de intervenção urbana, pedagogicamente estruturada, venha a emergir, acontecer e se alimentar da escola, tendo os próprios alunos como artistas-intervencionistas?

O ambiente escolar é o lugar próprio da educação e para que a arte possa ser exercida com propriedade nesse lugar que não está apropriado a ela, mas a um outro, é preciso que haja um movimento de interação entre educação e arte. Mas para que se provoque este movimento, é preciso uma atitude docente, principalmente por parte dos professores de artes, que os transformem em agentes culturais dentro do ambiente escolar. (ANDRÉ, 2007, p.93)

A provocação de André (2007) nos impeliu a pensar os possíveis modos de esquematizar e atrelar um processo artístico à um educativo. Para tentar formular uma resposta à questão, foi preciso antes repensar as relações entre educação e arte no ambiente escolar, logo, refletir sobre o ensino das artes nesse espaço. Diante das demandas dos sistemas de avaliação de desempenho, o ensino das artes na educação básica tem assumido uma perspectiva conteudista, na qual muitas vezes, as escolhas pedagógicas se pautam mais nas teorias e/ou na história das linguagens artísticas do que no fazer artístico. Faz-se necessário um posicionamento político, ético e estético do professor, de como ele percebe e legitima o lugar da arte na vida, no seu cotidiano, nas suas práticas e na escola.

A proposição do projeto Partida no espaço escolar se deu por acreditarmos que a intervenção urbana, como tendência estética do teatro contemporâneo sistematizada pedagogicamente para esse espaço, aproxima a arte da rua à escola. Ao intervir no ambiente escolar, o objetivo foi dialogar de outra forma com os sujeitos que compõem esta comunidade, ressignificando espaços e potencializando ações extra sala de aula. A intervenção urbana, neste contexto, viria a possibilitar e dar margem para que os estudantes pudessem se expressar e se experimentar artisticamente.

Durante a construção do projeto, foi definido que seria desenvolvido com alunas do ensino médio, da Escola Estadual de Educação Profissional Paulo VI, em Fortaleza/CE e que seria atravessado pela temática do aborto, debate extremamente necessário tanto do ponto de vista social, quanto do ponto de vista político e educativo. Foi planejado um cronograma de dois meses de atuação na escola, com dois encontros semanais. O primeiro mês destinado 
para uma abordagem focada na discussão de questões éticas e políticas que envolvem o aborto e, no mês seguinte, nos debruçaríamos a pesquisar, discutir e refletir sobre ações de intervenção urbana. Ao final do processo realizaríamos uma intervenção dentro do âmbito escolar, sendo as estudantes da escola as artistas-intervencionistas.

A noção de experiência permeou todo o projeto, desde a articulação das práticas, aos modos e às finalidades propostas. Desejávamos que todas as envolvidas tivessem uma experiência significativa de arte na escola, pois “a experiência é o que nos passa, o que nos acontece, o que nos toca” (BONDÍA, 2002, p.21), logo nos transforma.

O projeto PARTIDA foi o início de uma investigação, uma busca por encontrar outros modos de ensinar e aprender teatro, foi também uma tentativa de legitimar o espaço da arte na escola, portanto, não se finaliza aqui. Como etapa de meu processo formativo, mais um passo nesse campo em que ainda há muito que investigar, questionar e inquietar.

\section{Referências}

ANDRÉ, Carminda Mendes. O Teatro pós-dramático na escola (inventando espaços: estudos sobre as condições do ensino do teatro em sala de aula) São Paulo, Editora da Unesp, 2011.

BONDÍA, Jorge Larrosa. Notas sobre a experiência e o saber de experiência. Universidade de Barcelona, Espanha. 2002. 